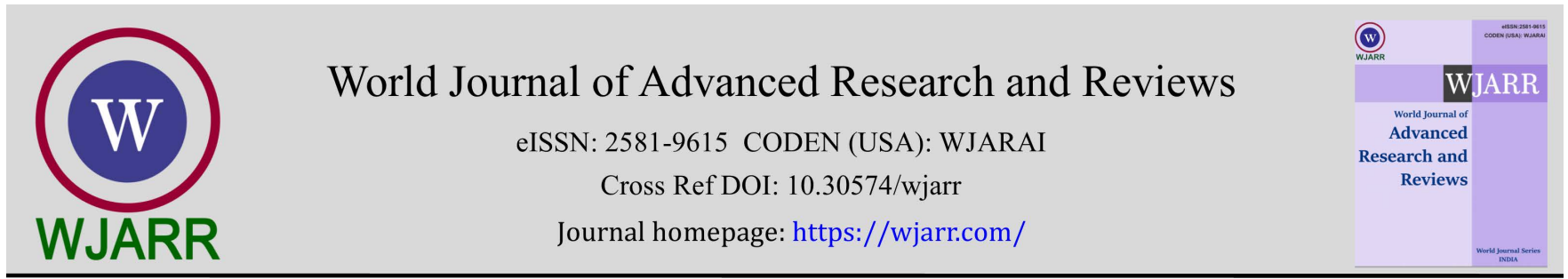

(RESEARCH ARTiCle)

\title{
Analysis of Coulomb Stress of Sumatera Earthquake Against Pyroclastic Flow of Mount Sinabung as Data Prone Volcano Disaster
}

\author{
Goldberd Harmuda Duva Sinaga $1{ }^{*}{ }^{*}$, Winarto Silaban ${ }^{2}$ and Ady Frenly Simanullang 3 \\ ${ }^{1}$ Mechanical Engineering, Universitas HKBP Nommensen Pematangsiantar, North Sumatra, Indonesia. \\ ${ }^{2}$ Biology Education, Universitas HKBP Nommensen Pematangsiantar, Pematangsiantar, North Sumatra, Indonesia. \\ ${ }^{3}$ Physics Education, Universitas HKBP Nommensen Pematangsiantar, Pematangsiantar, North Sumatra, Indonesia.
}

World Journal of Advanced Research and Reviews, 2022, 13(01), 793-803

Publication history: Received on 20 December 2021; revised on 29 January 2022; accepted on 30 January 2022

Article DOI: https://doi.org/10.30574/wjarr.2022.13.1.0086

\begin{abstract}
The islands of Sumatra and Sinabung are located southwest of the Sundaland Continent which is a convergence route between the Indian-Australian Plate that infiltrates to the west of the Eurasian/Sundaland Plate. The increase in activity of Mount Sinabung was preceded by large earthquakes to the west and south while the eruption of Mount Sinabung produced pyroclastics. The purpose of this study is to find out the analysis of coulomb stress from the Sumatra Island earthquake to the pyroclastic flow of Sinabung as data on volcanic disasters. This study used the coulomb stress method with coulomb 3.3. The earthquake data analyzed was Mw, depth, and focal mechanism. The results of the analysis in the form of the direction of the spread of stress and the value of increased coulomb stress in Sinabung in 2014-2016. Sinabung's positive stress coulomb value in 2014 was 0.113 bar with a positive coulomb stress spread angle of $90^{\circ}$ against sinabung pyroclastic flow. Sinabung's positive stress coulomb value in 2015 was 0.235 bar with a positive coulomb stress spread angle of $90^{\circ}$ against sinabung pyroclastic flow. Sinabung's positive stress coulomb value in 2016 was 0.118 bar with a positive coulomb stress spread angle of $90^{\circ}$ against sinabung pyroclastic flow. Coulomb stress analysis affects the direction of prioclastic flow by as far as $180^{\circ}$ although it is not the same as the results in the field. This is because the peak of Sinabung has landslides in the southeast-south, thus opening a pyroclastic flow road to the southeast-south.
\end{abstract}

Keywords: Earthquake; Coulomb Stress; Sinabung; Pyroclastic

\section{Introduction}

Mount Sinabung is a strato volcano in Karo Regency, Indonesia. The geographical position of the summit of Mount Sinabung at latitude $3^{\circ} 10^{\prime} 16.7^{\prime \prime} \mathrm{LU}$ and longitude $98^{\circ} 23^{\prime} 24.66^{\prime \prime}$ with elevation of 2460 mean sea level. In general, mount Sinabung eruption products are pyroclastic flows and lava flows. The eruption of Mount Sinabung has brought volcanic ash and other materials covering the ground. Eruption material consists of large to fine-sized rocks, which are rough in size usually falling around radius of 5-7 km from the center of the eruption, while the fine-sized can fall at distances of hundreds to thousands of kilometers (1)(2). The nature of Sinabung eruption is a weak-medium explosive eruption that produces ash eruptions (early eruptions) and is likely to end an effusive eruption that produces lava flows, therefore the potential for pyroclastic formation (stone throwing and ash rain) is quite significant. The pyroclastic flow Sediment Unit is predominantly sand-sized tietan chunks, fragments of andesitan rock sand-sized pumice, and fairly solid gravel. scattered in the south and central part of filling the gap of panyabungan depression covering the structure of the sesar. More complex volcanoes may be more susceptible to earthquake triggering. The slower than expected decay in triggering distance may indicate the presence of coupling via deeper tectonics and a nonlinear volcanic response to stress perturbations (3). The distribution of Aceh aftershocks on December 26, 2004 resulted in a positive

\footnotetext{
* Corresponding author: Goldberd Harmuda Duva Sinaga

Mechanical Engineering, Universitas HKBP Nommensen Pematangsiantar, North Sumatra, Indonesia. 
coulomb failure stress change ( $\triangle \mathrm{CFS}$ ) change of $49.8 \%$ while $\Delta \mathrm{CFS}$ was negative at $50.2 \%$. This shows that elastic halfspace modeling for interplate/mega thrust zone earthquakes still does not represent a good but consistent relationship to intraplate earthquakes (4). Increased coulomb stress (coulomb stress change) that is of positive value can trigger or trigger an earthquake. The Aceh earthquake with Mw9.0 and the earthquake with $\mathrm{Mw}>7$ which resulted in a positive coulomb stress change in the Mount Sinabung area and its surroundings triggered a devastating eruption on August 27, 2010. High seismic activity in areas that have undergone positive stress coulomb changes indicates the high stress of the Earth's crust that is scattered in the northern part of Sumatra (5). This case has already occurred in several regions in Indonesia such as Aceh (4)(6), Halmahera (7), Pidie Jaya (8), Papua (9), Palu (10), China (11)(12)(13), and Iran (14). Primary sources of seismic, geodetic, and tsunami observations indicate that for the six model sources tested, there was an average increase of $47 \%$ in the positive pressure aftershock mechanism of the earthquake (1997-10 March 2011) (15). In general, this study is based on observations earthquake precursors such as seismic parameters (Vp/Vs, seismic, b-value), type and EM parameters, gravity, tides, Radon gas, temperature, humidity and other physical parameters.(16) According to Estu (2018) (17), the implication of pyroclastic fall in Indonesia, with modeling with a $5 \mathrm{~km}$ eruption scenario produces a map of ash scattering with a thickness of $0.1-5 \mathrm{~mm}$ that hit around Mount Sinabung a radius of 10 $\mathrm{km}$ from the center of the eruption and to the southwest with an impact distance of $20 \mathrm{~km}$. Forecast of the impact of volcanic ash on population and land cover on the surface due to the eruption of Mount Sinabung on 19 February 2018. Noto Hanto's well-recorded aftershock resulting in an aftershock zone quickly developed into a 'butterfly pattern' predicted by static coulomb stress transfer associated with thrust faults (18). The seismic and post-earthquake stress changes caused by the Wenchuan earthquake significantly increased stress accumulation in the hypocenter of the Jiuzhaigou earthquake (19). Comparison of CFF values for earthquakes before and after the Tohoku-Oki earthquake shows that the last earthquake has a more positive value; thus supporting the hypothesis of a coseismic stress change transferred from the Tohoku-Oki earthquake sequence (20)(21).

According Agoes (2017) (22), in pyroclastic simulation research in Sinabung in 2016 resulted in an overlay between hot cloud landaan areas with a scenario of 3 million $\mathrm{m}^{3}$ on the disaster prone areas map showing the range of hot cloud flows in the southeast, west and northeast sectors has slightly crossed the third disaster prone areas map boundary (a region very potentially hit by hot clouds, lava flows, lava drop and toxic gas). A pyroclastic flow is a flow of heat with a high concentration, surface debt, moving, in the form of gases and dispersed particles produced by volcanic eruptions (23). Pyroclastic flow is also a flow of particle density and gas in hot conditions generated by volcanic activity. Pyroclastic flows involve all flows produced by small eruptions or large lava flows. Pyroclastic flows are controlled by gravity and flow through low-lying areas/valleys. The high mobility of pyroclastic flows depends on gases from magma, lava, and air as they flow. The flow speed can reach $150-250 \mathrm{~km} / \mathrm{hour}$, and the flow range can reach tens of kilometers even though it moves on water/sea. Pyroclastic flows occur due to the explosion of high smoke poles, when the energy runs out, the ash will spread towards the wind, then fall again to the earth's surface. The author combines coulomb stress and pyroclastic flow into the results of a new study so as to produce the influence and direction of Sinabung pyroclastic flow data based on Newton's law. Based on the hypothesis, the pyroclastic flow of the Sinabung eruption is thought to be influenced by changes in stress from the earthquake that occurred on the island of Sumatra. The author hopes that the results of the combination of coloumb stress and pyroclastic flows can be useful for residents around the volcano, especially people on Mount Sinabung to be more alert in dealing with catastrophic eruptions.

\section{Material and methods}

The method used is descriptive analysis, namely by explanation and analysis through the coulomb stress model, where the data is processed and then the results of the coulomb stress change are obtained. The model used in this research is The coulomb stress model which is programmed in Coulomb 3.3 software. The data needed in this study is 2014-2016 earthquake data in the form of earthquake location, magnitude, depth, earthquake type, strike, slip, dip, and moment tensor. This data is processed and then produces a value of change in the the coulomb stress in positive or negative form and then displayed in the form of 2D and 3D vector maps. With this method, the spread of earthquakes is obtained as a result of tectonic earthquake interactions against the pyroclastic flow of Sinabung. Then the display is compared with the direction of the pyroclastic flow so as to produce connection between coulomb stress and pyroclastic flow. Elastic Dislocation modelling based on angular dislocation theory is able to predict displacement fields and the distribution ofstrain in a poroelastic medium for any slip introduced on a discrete fault (24).

Earthquake interaction by static stress transfer can occur among faults of differing orientations, rakes and depths. Static stress changes may affect seismicity for periods on the order of 1 year in the Gorda zone, and perhaps for over a decade in the case of $M>7.2$ earthquakes Mendocino Fault Zone, Cascadia subduction zone, and northern San Andreas Fault (25). The original idea of rock mechanics was first put forward by Amonton in 1699 which was subsequently developed by Coulomb in 1733 (26). Amonton provides a formula that is then referred to as the second law of Amonton formulated as in the Equation 


$$
\tau=\mu_{\mathrm{s}} \sigma_{\mathrm{n}}
$$

With $\tau$ is the pressure required to make a rock break (bar or pa), $\mu_{\mathrm{s}}$ is a static friction coefficient, and $\sigma_{n}$ is a normal voltage that works on rocks (bar or Pa). Earthquakes occur when a pressing shear voltage that works on a fault large enough to overcome a normal voltage (clamp), in combination with friction, blocks the clamp fault from slipping. This balance can be characterized by the criteria of coulomb failure (27)(28) the stress of critical Coulomb failure, $\sigma_{c}$, given by

$$
\sigma_{\mathrm{c}}=\tau-\mu\left(\sigma_{\mathrm{n}}-\mathrm{p}\right)
$$

In coulomb criteria, a fault occurs in a field when coulomb stress $\sigma_{\mathrm{f}}$ exceeds a specific value (29).

$$
\sigma_{f}=\tau_{\beta}-\mu\left(\sigma_{\beta}-p\right)
$$

Where $\tau_{\beta}$ is the shear voltage on the fault area, $\sigma_{\beta}$ is the normal voltage, $p$ is the fluid pore pressure and $\mu$ is the coefficient of friction. Potential slips lead to the right or to the left. The value of $\sigma$ in this case should always be positive, but otherwise the process that takes place in finding the stress value to the fault can be given both positive and negative values depending on the potential slip pointing to the right or to the left. In the orientation fault field $\beta$ to the angle of $\sigma_{1}$ we can refer to the stress component shown to him as the main stress.

$$
\sigma_{\beta}=\frac{1}{2}\left(\sigma_{1}+\sigma_{3}\right)-\frac{1}{2}\left(\sigma_{1}+\sigma_{3}\right) \cos 2 \beta
$$

In systems where the x-axis and $y$-axis and fault displacement are horizontal and vertical field faults (including the xdirection), the voltage on the field as the angle of the $\psi$-axis is given

$$
\tau_{13}=\frac{1}{2}\left(\sigma_{\mathrm{yy}}-\sigma_{\mathrm{xx}}\right) \sin ^{2} \psi+\tau_{\mathrm{xy}} \cos ^{2} \psi
$$

From the equation above, it can be written down the change of coulomb stress to the right lateral $\sigma_{f}^{R}$ and left lateral $\sigma_{f}^{L}$ submitted in a field oriented with a $\psi$ the $x$-axis

$$
\begin{gathered}
\sigma_{f}^{R}=\tau_{13}^{R}+\mu^{\prime} \sigma_{33} \\
\sigma_{f}^{L}=\tau_{13}^{L}+\mu^{\prime} \sigma_{33}(7) \\
\text { or } \\
\Delta \mathrm{CFF}=\Delta \tau+\mu_{\mathrm{s}} \Delta \sigma_{e}
\end{gathered}
$$

Changes in stress are illustrated by graded colors; green represents no change in stress. red represent change in stress. In coulomb, we will explore four types of fault receivers: the "determination" of fault receivers where all faults have uniform fault receiver geometry; faults optimally oriented for faults; fault receivers on geometry set in input files, and; file focal mechanisms, where there are always two orthogonal fault fields. Optimal orientation is a function of regional stress (also called "tectonics"), stress is passed on the source of the fault, and the coefficient of friction is assumed in the fault receiver.

Deterministic coulomb stress calculations provide important results based on our physical process understanding. Therefore, it is desirable to use these additional deterministic information, if available, for seismicity modeling. In the past, Coulombstress calculations have been often shown to be very successful in describing overall features of triggered seismicity. However, even on the short time scales, purely deterministic approaches are not able to describe the details of the earthquake dynamics. The existence of small scale stress and material heterogeneities, which will be in general not accessible to direct measurements, will preclude the possibility of purely deterministic earthquake predictions. However, although pure deterministic approaches are not applicable, our physical knowledge should not be ignored because it gives important constraints. In order to advance in the field of earthquake forecasting, deterministic and probabilistic approaches should be combined to end up with physics-based probabilistic models. Some promising steps are already done in the context of the stress-based seismicity models (30). The aftershocks' mechanisms are strongly related to the deformation field caused by the mainshock, the displacement directions always nearly parallel to the maximum principal stress directions or the shear directions of the aftershocks' focal mechanism solutions (31). 


\section{Results and discussion}

The characteristics of earthquakes used in coulomb stress are earthquakes located around Sumatra with a minimum magnitude of 5.8 Mw with the direction of strike, dip, rake and focal mechanism form. While the spread of earthquake energy depends on strength, depth, and direction of stress and strains. The earthquake used was the initial earthquake of December 26, 2004 - May 2016 that occurred in the north of Sumatra. The selection of this earthquake is because it wants to see the effect of stress /strains of the earthquake on the pyroclastic flow of the eruption of Mount Sinabung. The modeling used is coulomb stress using Coulomb 3.3.'

\subsection{Coulomb Stress Changes of December 2004-2014 Sumatra Earthquake}

The earthquake, which occurred between December 26 until January 11, 2014, had a strength of $5.0 \mathrm{Mw}-9 \mathrm{Mw}$ in the Indian Ocean, northern Sumatra and India's Nicobar Islands. The earthquake that occurred on the island of northern Sumatra (6) and its surroundings that occurred in the period December 26, 2016 to January 11, 2014 resulted in the distribution of positive value stress coulomb on Mount Sinabung. Sinabung get an increase in stress marked by a red lobe/orange lobe. The red lobe/orange lobe on Mount Sinabung was caused by a major earthquake that initially occurred on December 26, 2004 and was followed by 3 aftershocks with a magnitude of 7.2, 7.8, and 8.6 Mw with longitude coordinate points $3.36^{\circ}, 2.07^{\circ}$, and $1.67^{\circ}$ latitude $95.78^{\circ}, 96.74^{\circ}, 97.07^{\circ}$ strike-slip and reverse fault types. The earthquakes occurred in 2010 and 2005. The figure 1 show the selection of cross section direction based on the prioclastic flow direction of Mount Sinabung depth of $100 \mathrm{~km}$ that occurs is southeast with the average value of coulomb positive stress range is 0.133 bar on depth $0-100 \mathrm{~km}$ (figure 2). The value of stress in the northwest - southeast has a sufficient effect on the increase in volcanic activity of Mount Sinabung. This is in accordance with previous research stating that the increasing volcanic activity of Mount Sinabung is due to the situation in the Sinabung mountain area experiencing a large press force (5). It is shown that there is an apparent correlation between the stress changes and the observed spatial pattern of the aftershock occurrence supporting use of near-real time estimate of the stress changes as tool for earthquake hazard mitigation (32).

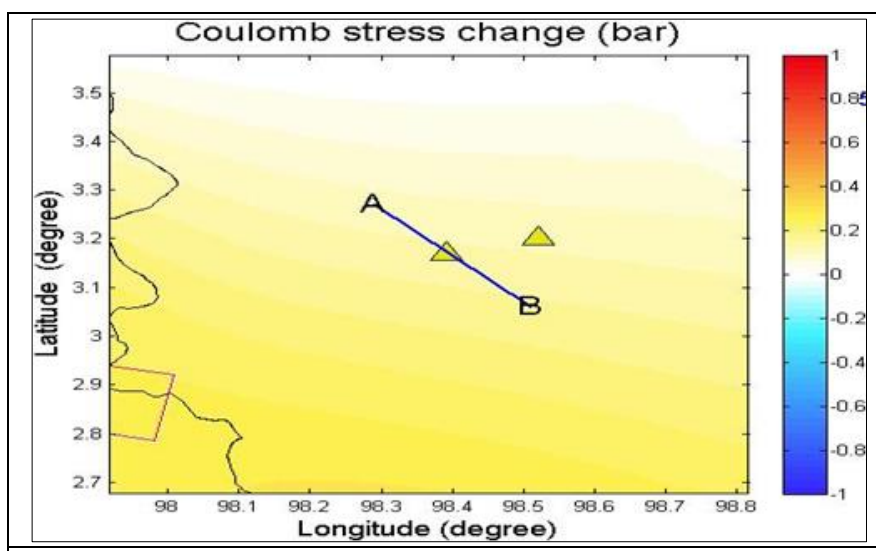

Figure 1 Map of sinabung mountain area (2004-2014)

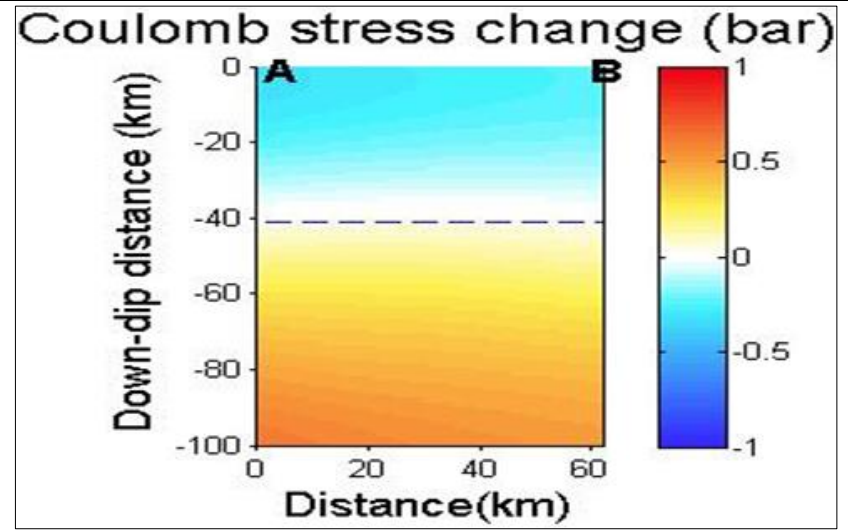

Figure 2 Cross section A-B changes Coulomb Stress under Mount Sinabung during the December 26, 2004January 11,2014 earthquake at a depth of $10 \mathrm{~km}$

Figure 3 shows the change in coulomb stress affected by the December 26, 2004 earthquake and 3 other major earthquakes. The direction of vector coulomb stress change is more skewed towards the northwest, while the direction of the pyroclastic flow skews to the east and southeast. The difference in direction of the coulomb vector stresses against the pyroclastic flow of $90^{\circ}$. However, if its like seen at the history of the $9.0 \mathrm{Mw}$ earthquake that occurred on Sumatra Island in 2004, the direction of coulomb stress is leaning more towards the northwest as far as $90^{\circ}$ against pyroclastic flows (Figure 4). Due to the pyroclastic flow, several villages were affected, especially in the southeastern areas namely Sukameriah, Bekerah, Simacem, Gamber, Gurukinayan, Berastepu, and Sibintun Hamlet. And to the east of the affected areas are Bekerah, Sukameriah, Simacem, Sukanalu, Kutatonggal (16). 


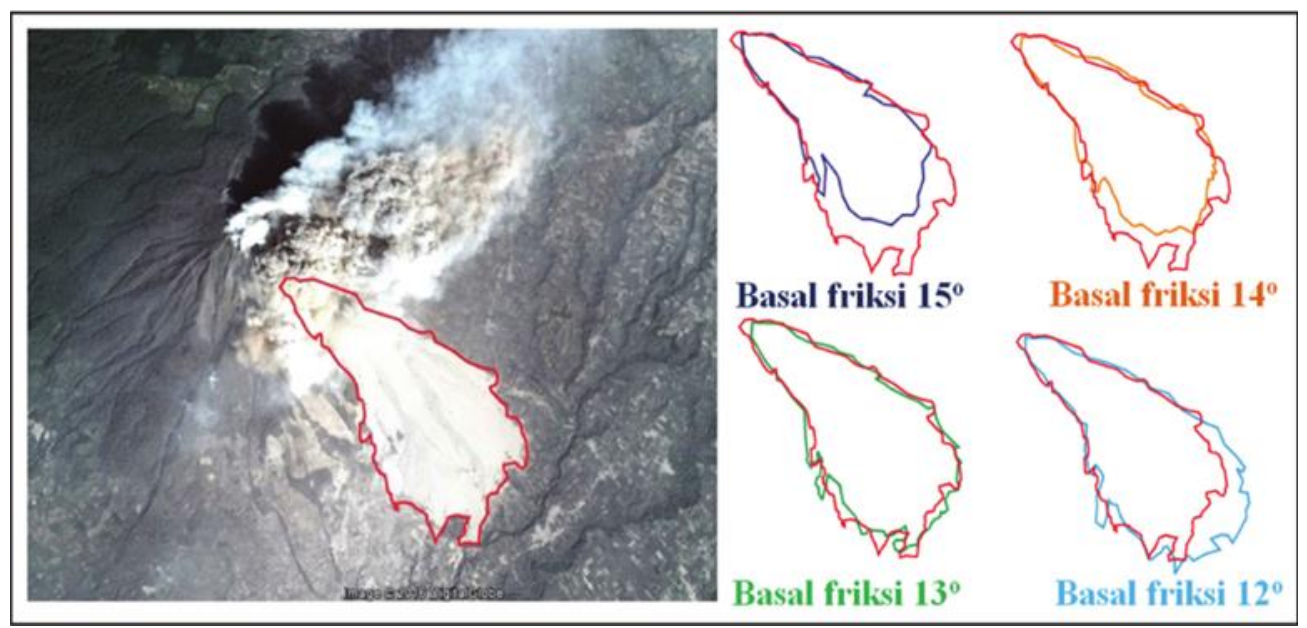

Figure 3 Pyroclastic Flow of Sinabung January 11, 2011(22)

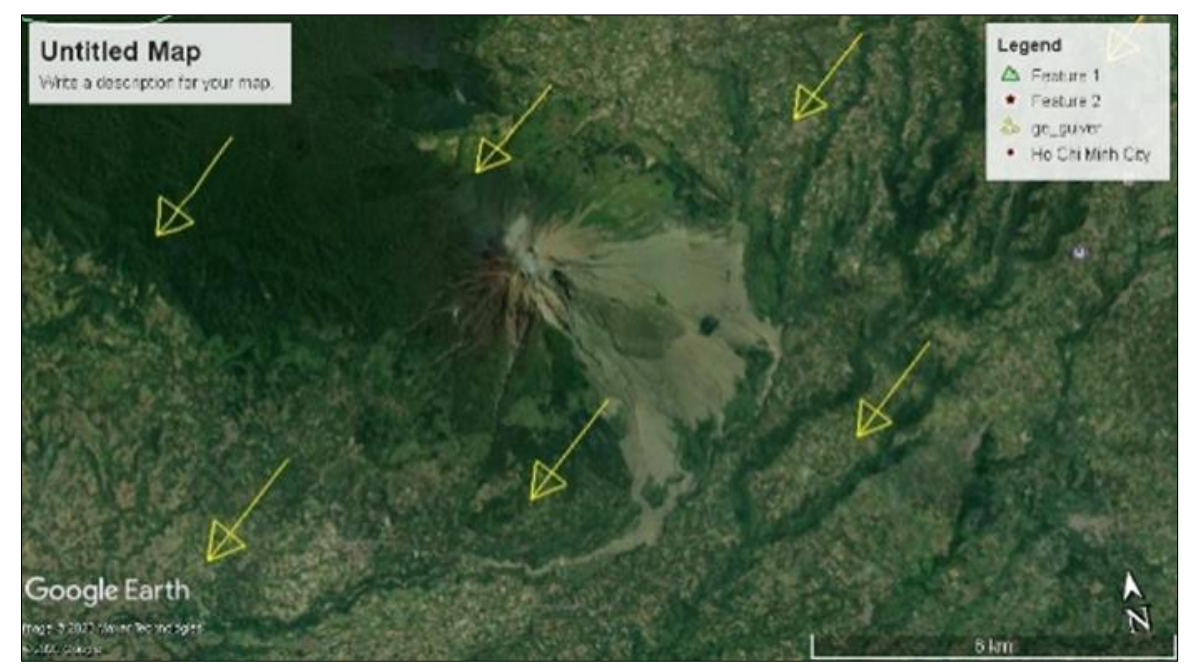

Figure 4 Display of coulomb stress change vector direction in Sumatra during the earthquake of December 26, 2014 January 11, 2014 at an altitude of $7 \mathrm{~km}$

\subsection{Coulomb Stress Changes of December 2004-2015 Sumatra Earthquake}

The earthquake, which occurred between December 26 until April 28, 2015, had a strength of $5.0 \mathrm{Mw}-9$ Mw with locations in the Indian Ocean, northern Sumatra and India's Nicobar Islands. The earthquake in northern Sumatra resulted in a positive distribution of stress coulomb on Mount Sinabung. Figure 5 shows the area of Mount Sinabung experiencing stress marked with a red lobe. The red lobe on Mount Sinabung was caused by a major earthquake that initially occurred on December 26, 2004 and was followed by 3 aftershocks whose magnitude was 6-6.1 Mw with longitude coordinate points of $4.33^{\circ}$ and $1.72^{\circ}$ latitude $92.69^{\circ}$ and $96.74^{\circ}$ with strike-slip and reverse fault types and aftershocks of $6.4 \mathrm{Mw}$ with a longitude of $7.73^{\circ}$ and latitude $94.32^{\circ}$ leading to the northwest and north.

Increased stress in Mount Sinabung is also supported by increased activity of Mount Sinabung as evidenced by seismic data presented by PVMBG. Figure 6 show the cross section A-B image with a northwest-southeast direction with a depth of $100 \mathrm{~km}$ in the Sinabung area that is experiencing increased stress is shown a reddish yellow color. The cross section results of this coulomb stress change work at a distance of $10 \mathrm{~km}$ which is in the northwest - southeast with the average value of this positive stress coulomb range of 0.235 bar. The stress value is enough to influence the increase in volcanic activity of Mount Sinabung. 


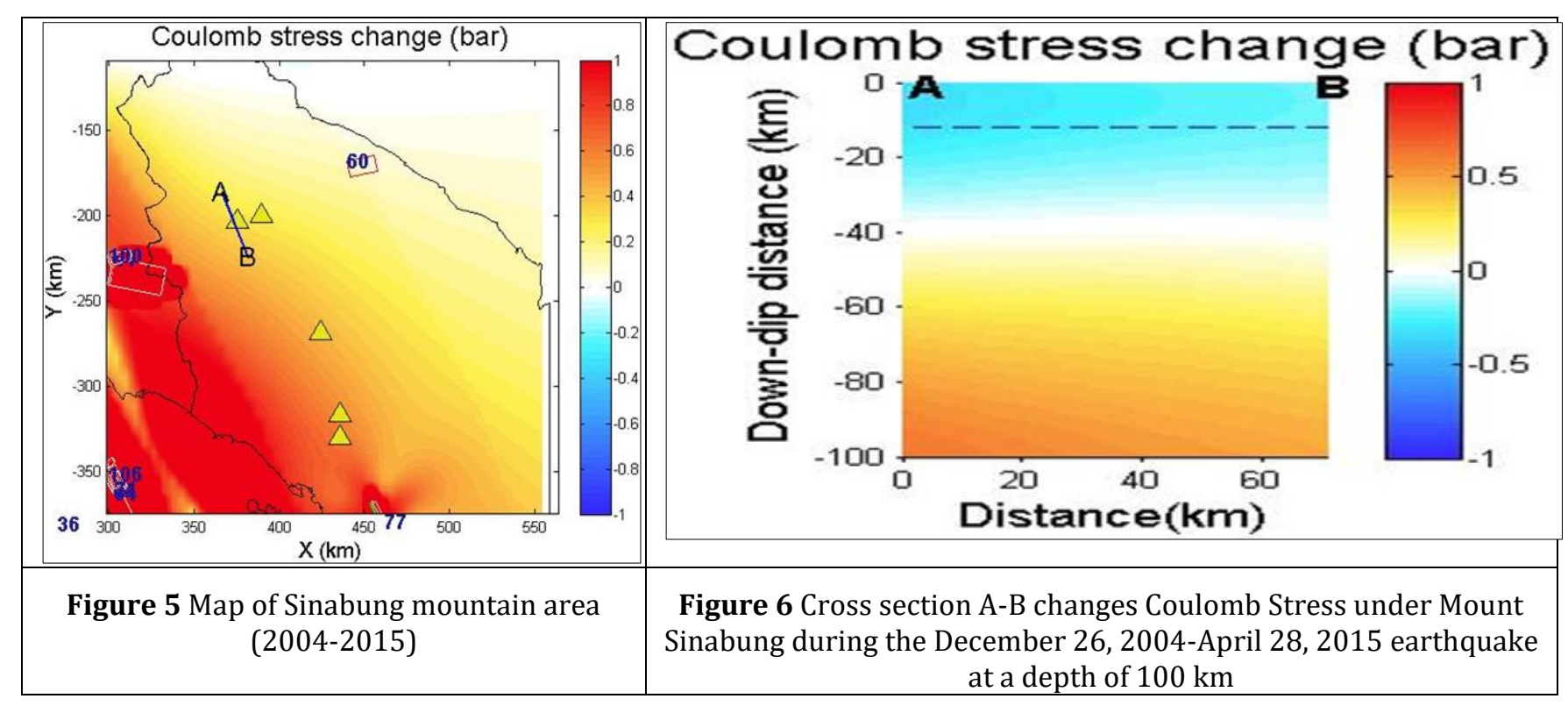

The value of coulomb stress in 2015 increased compared to 2014. The increase in the value of coulomb stress was due to a 6.4 earthquake that occurred in India's Nicobar Islands in 2015. The increase in the value of coulomb stress in Sinabung in 2015 also resulted in an increase in volcanic activity.

This phenomenon is appropriate and supports previous research stating that the increasing volcanic activity of Mount Sinabung is caused by the situation in the Sinabung mountain area experiencing a large press force (5). Similar cases have also been on Mount Soputan and Gamalama whose increased activity is influenced by increased coulomb stress characterized by red lobes (33). Figure 7 shows the direction of the coulomb stress change vector is still leaning more towards the southwest even though in 2015 there has been an increase in northern coulomb stress.

The direction of coulomb stress is dominated by the magnitude 3 earthquake closer to mount Sinabung in 2014 with magnitude 6.4 at the Longitude coordinates of $1,67^{\circ}$ latitude $97.46^{\circ}$. While the direction of the pyroclastic flow skews east and southeast so that the angle between vectors against pyroclastic flow is $90^{\circ}$. Although the large angle of direction of the coulomb vector stresses against the pyroclastic flow is still $90^{\circ}$, but the direction of the pyroclastic flow has begun to expand towards the northeast. The widespread direction of this pyroclastic flow indicates there will be a change in angle between the coulomb vector stress against the pyroclastic flow, in the event of a major earthquake resulting in a change in coulomb stress at the coordinates of the longitude $0^{\circ}-2^{\circ}$ and latitude $97^{\circ}-99^{\circ}$. The impact of pyroclastic flow still covers the southeastern areas namely Sukameriah, Bekerah, Simacem, Gamber, Gurukinayan, Berastepu, and Sibintun Hamlet. And to the east of the affected areas are Bekerah, Sukameriah, Simacem, Sukanalu, Kutatonggal.

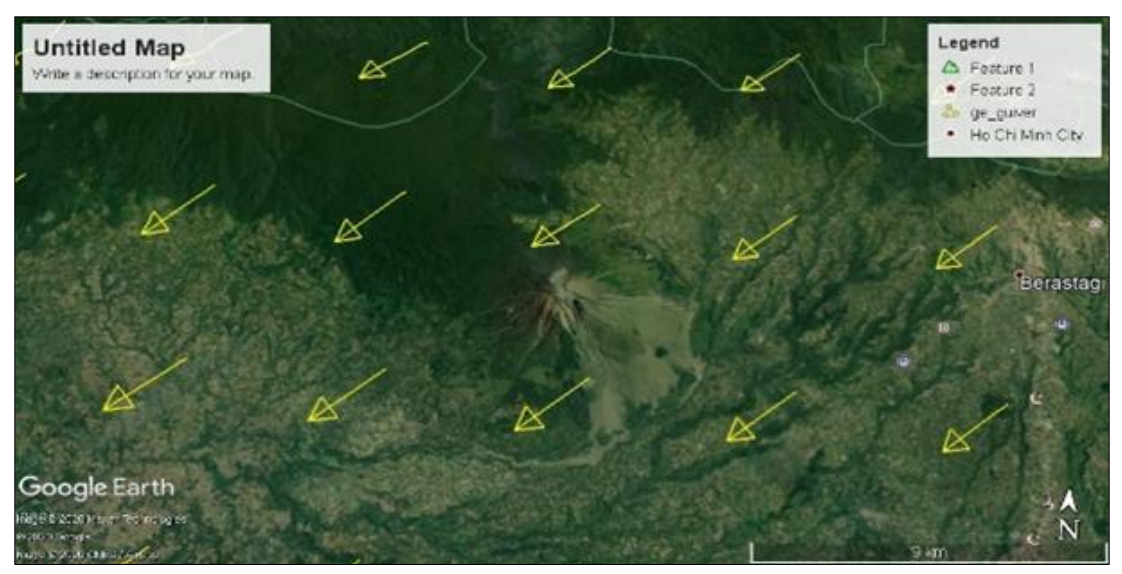

Figure 7 Display of coulomb stress change vector direction in Sumatra during the Earthquake of December 26, 2014 April 28, 2015 at an altitude of $9 \mathrm{~km}$ 


\subsection{Coulomb Stress Changes of December 2004-2016 Sumatra Earthquake}

The earthquake that occurred from December 26, 2004 to May 2016 had a magnitude of 5.0 - 9.0 Mw with earthquakes spread across the northern Sumatra, Indian Ocean, and Nicobar Islands of India. With the smallest magnitude of 5.0 SR occurring on December 27, 2012 in the Nicobar Islands of India while the largest magnitude of 9.0 SR occurred on December 26, 2004 in the Sea Off the Coast of northern Sumatra or in the Indian Ocean. The earthquake that occurred on the island of northern Sumatra and surrounding areas from December 26, 2016 to May 2016 resulted in a positive distribution of stress coulomb in Sinabung. The red lobe on Mount mount Sinabung was caused by a major earthquake that initially occurred on December 26, 2004 and was followed by several aftershocks that were one of magnitude 6.5 Mw (2015) with strike-slip and reverse fault types (Figure 8). The earthquake caused stress in the west-southwest region and produced a red lobe in western-southwestern Sumatra. While the negative lobe marked in blue is still spreading north. Figure 9 shown cross section results of coulomb stress changes that work at $10 \mathrm{~km}$ have a average value of positive stress coulomb values of 0.118 bar. The value of stress in the northwest-southeast decreased but influenced the increase in volcanic activity of Mount Sinabung. The decrease in the value of coulomb stress due to the 6.5 Mw earthquake describes the stress in the area that occurred in longitude $6.76^{\circ}$ latitude $94.78^{\circ}$. From these traces can be inferred that changes the increase in coulomb stress (coulomb stress change) that is positive with prices range from $0<\sigma f>1$ bar can trigger or triggering the next earthquake. In this case is worth from 0.8 bar to 1.0 bar (34)(35). Although the value of coulomb stress in mount Sinabung in 2016 decreased but the value of coulomb stress still affects volcanic activity.

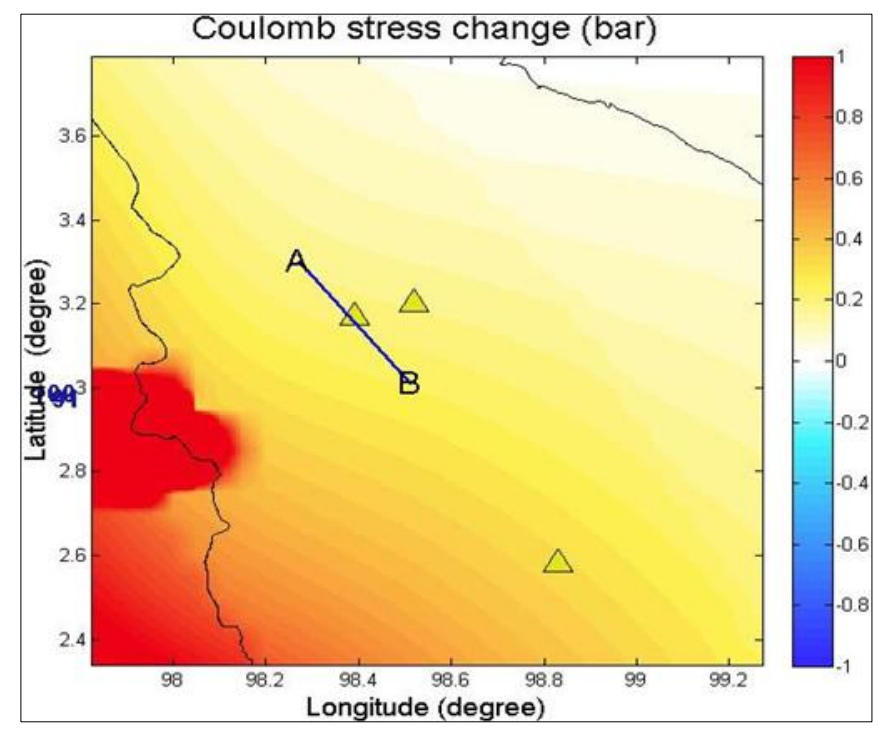

Figure 8 Map of Mount Sinabung (2004-2016)

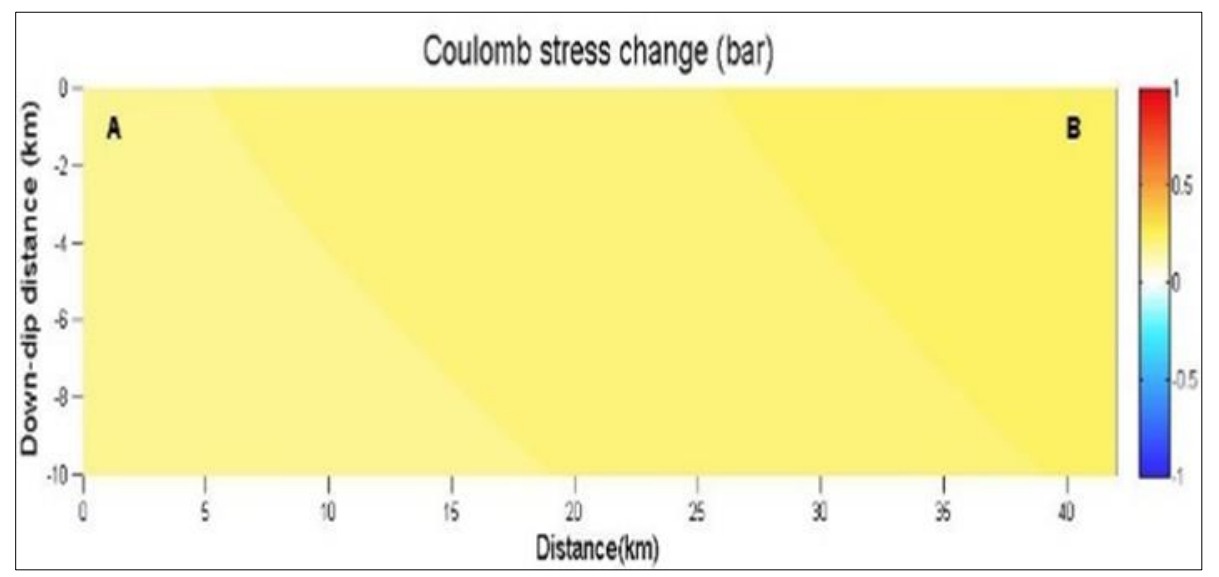

Figure 9 Cross section A-B changes coulomb stress under Mount Sinabung during the December 26, 2004-May 21, 2016 earthquake at a depth of $10 \mathrm{~km}$ 


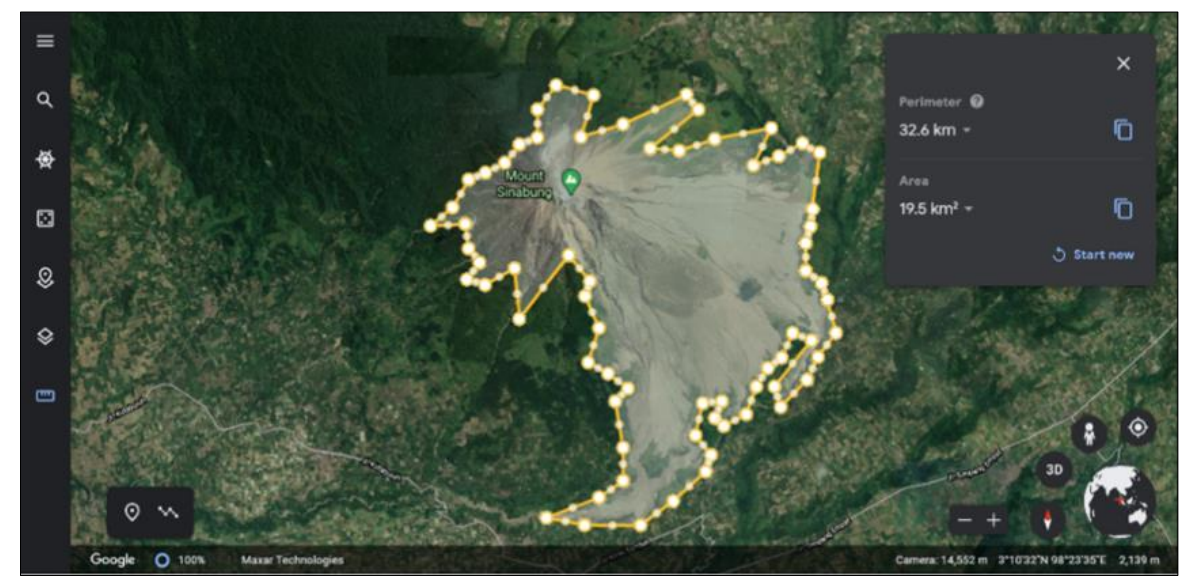

Figure 10 Direction of deployment of stress coulomb based on vector

The December 26, 2004 earthquake affected the volcanic activity of Mount Sinabung as well as the volcanoes that existed in Indonesia and spread throughout the place (36)(37)(38). Figure 10 show the change in pyroclastic flow that occurred ay 21, 2016. Laborus River until it reached Gamber Village (16). The spread of stress coulomb is converted to a vector shape resulting in a southwest direction with a difference as far as $90^{\circ}$ in the form of arrows.

Table 1 Coulomb Stress Vector Direction Comparison for Pyroclastic Flow Direction

\begin{tabular}{|c|c|c|c|c|}
\hline No & $\begin{array}{l}\text { Year } \begin{array}{r}\text { and } \\
\text { Direction vector } \\
\text { Coulomb Stress }\end{array} \\
\text { Pyroclastic Flow }\end{array}$ & $\begin{array}{l}\text { Direction Mountain } \\
\text { Pyabung }\end{array}$ & $\begin{array}{l}\text { Stress/Strain } \\
\text { average } \\
\text { (+/- Bar) }\end{array}$ & $\begin{array}{l}\text { Angle } \\
\text { stress } \\
\text { Pyroclastic Flow } \\
\text { to }\end{array}$ \\
\hline 1 & $2014 /$ Southwest & East-southeast & 0.133 bar & $90^{\circ}$ \\
\hline 2 & $2015 /$ Southwest & East-southeast & 0.235 bar & $90^{\circ}$ \\
\hline 3 & $2016 /$ Southwest & North - northeast - Northeast-Southeast & 0.118 bar & $90^{\circ}$ \\
\hline
\end{tabular}

The dominant pyroclastic flow leads south, southeast, east and slightly to the north. The area of pyroclastic flow based on google earth imaging is $19.5 \mathrm{~km}^{2}$ and the perimeter is $32.6 \mathrm{~km}^{2}$ (table 1). As for the villages affected by the flow in the southeast (Sukameriah village, Bekerah, Simacem, Gamber, Gurukinayan, Berastepu, and Sibintun Hamlet) east (Bekerah, Sukameriah, Simacem, Sukanalu, Kutatonggal) south (Mardinding, Perbaji, Gurukinayan, Sukameriah, Berastepu, Sibintun Hamlet) and northern areas (Lau Kawar, Kutagugung, Sigarang-garang). River until it reached Gamber Village (16). The pyroclastic flow of Mount Sinabung stopped after passing through the Laborus The spread of stress coulomb is converted to a vector shape resulting in a southwest direction with a difference as far as $90^{\circ}$ in the form of arrows.

The vector direction was caused by the addition of 4 major earthquakes and aftershocks in the Indian Ocean and Nicobar Islands of India that occurred in the southwest with a magnitude of 6.0-6.5 Mw (2014-2016) with strike slip and reverse fault types. The type of fault that strike slips and reverses from the fault produces a large stress value by heading northeast and southwest which increases the stress value of the surrounding geological conditions. The direction of the vector changes coulomb stress from the earthquake of May 21, 2016 inversely $90^{\circ}$ with the direction of pyroclastic flow. But when compared to pyroclastic directions in 2014, 2015, and 2016, it can be the resultant styles that work on objects are equal to zero. $(\mathrm{F}=0)$. This can be seen if the stress direction of the geology in Sinabung leads to the southwest, then the pyroclastic flow moves to the northeast and if it leads to the northwest then the pyroclastic flow leads southeast or to the area that is experiencing strains. If an area gets a stress/stress area, then the area is most likely to have aftershocks that result in increased volcanic activity of Mount Sinabung (5) and pyroclastic flows leading opposite the area of earthquake activity (Newton Law I).

$$
\begin{gathered}
\sum \mathrm{F}=0 \\
\mathrm{~F}_{\text {stress }}+\mathrm{F}_{\text {fluida }}=0
\end{gathered}
$$




$$
\begin{gathered}
F_{\text {stress }}=-F_{\text {fluida }} \\
\Delta \mathrm{CFF}=-\mathrm{F}_{\text {fluida }} \\
\Delta \tau+\mu \Delta \sigma=-\mathrm{F}_{\text {fluida }} \\
\mathrm{F}_{\text {pyroclastic }}=-(\Delta \tau+\mu \Delta \sigma)
\end{gathered}
$$

From the equation 10 above, $F_{\text {stress }}$ can be assumed to be a press force by stress caused by earthquakes accompanied by parameters of strength, depth, strike, dip, slip, and fault type. While $F_{\text {fluida }}$ can be assumed the thrust force of the pyroclastic flow consisting of characteristics (temperature, density, pressure, density of fluids) and material composition (hydrogen, carbonmonooxide, carbondioxide, hydrogen sulfide, sulfur dioxide, sulfur trioxide, chlorine and hydrochloric acid) of the pyroclastic.The negative direction in equation 11 indicates that the direction of pyroclastic flow is always in contrast to the direction of positive coloumb stress change.

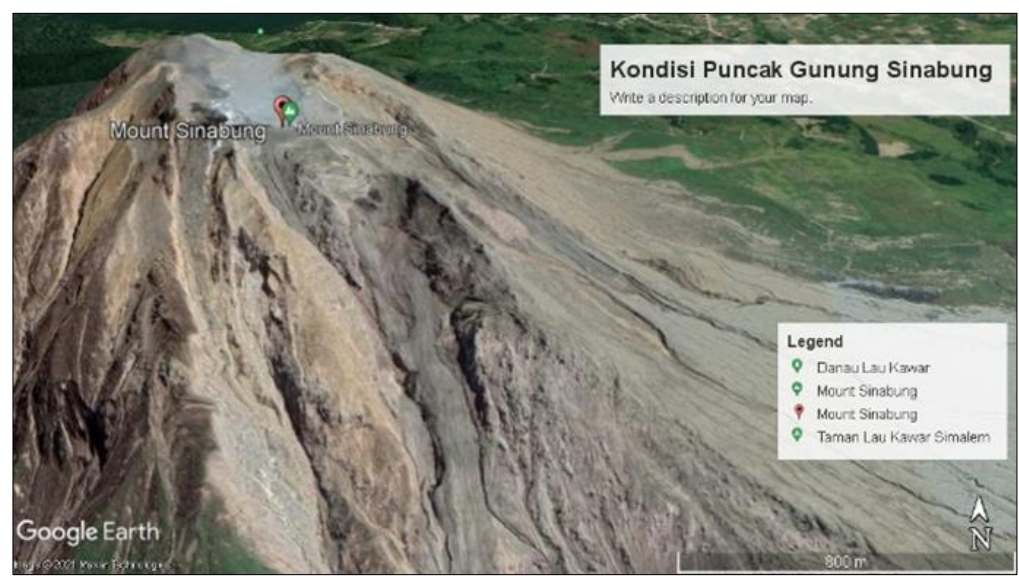

Figure 11 The condition of Peak Sinabung which landslides after eruption

Comparing the direction of coulomb stress to pyroclastic flow, the author assumes that the direction of stress affects the direction of prioclastic flow by 180 degrees even though the results in the field are very different. This is caused by the peak of Sinabung experiencing landslides in the southeast and south as shown in figure 11. The results of this study are expected to be deeper in physical equations that adopt Newton's laws so that they can provide new information in the field of geophysics and benefit the public about the awareness of pyroclastic flows during the Sinabung eruption.

\section{Conclusion}

The Coulomb Stress model with Software 3.3 produces data in the form of positive stress values of 0.133 bar (2014), 0.235 bar (2015), and 0.118 bar (2016). In addition, the coulomb stress model produces data in the form of a positive stress direction of 90 degrees to the direction of pyroclastic flow from 2014-2016. Although the angle of comparison differs by 90 degrees, the assumption of a positive stress direction is 180 degrees based on Newton's first law. This 's due to southeast and south Sinabung peaks that collapsed during early eruption Sinabung, opening the way for pyroclastic flows.

\section{Compliance with ethical standards}

\section{Acknowledgments}

The author thanked BMKG Indonesia, PVMBG Indonesia, USGS, and Global CMT for the availability of data that can be obtained online so that this research can be completed and published. The author hopes this paper can be useful to all parties, especially the people around mount SInabung and related parties so that it becomes a reference if there is a volcanic eruption. 


\section{Disclosure of conflict of interest}

The co-author and other research members completed the study together. In addition, the following staff of researchers from BMKG Indonesia and PVMBG Indonesia also played a role in the research and writing of the results of this study so that it can be published and can be known by the wider community about the influence of coulomb stress on pyroclastics.

\section{References}

[1] S Udaryo, S Utjipto. Vulkanik Di Daerah Cangkringan Kabupaten Sleman. 2009; 715-722.

[2] S Nakada, et al. Eruption scenarios of active volcanoes in Indonesia, J. Disaster Res. 2019; 14(1): 40-50.

[3] MS Bebbington, W Marzocchi. Stochastic models for earthquake triggering of volcanic eruptions, J. Geophys. Res. 2011; 116(B5): 1-16.

[4] SPAG (GAW), B Kototabang, BMK dan Geofisika. KAJIAN HUBUNGAN ANTARA DISTRIBUSI GEMPA SUSULAN ACEH 26 DESEMBER 2004 TERHADAP DISTRIBUSI PERUBAHAN TEKANAN COULOMB (COULOMB STRESS CHANGE), Megasains. 2013; 3: 133 - 139.

[5] SPAG (GAW), B Kototabang, BMK dan Geofisika. HUBUNGAN ANTARA GEMPABUMI DENGAN ERUPSI GUNUNGAPI STUDI KASUS ERUPSI GUNUNG SINABUNG TAHUN 2010 DAN 2013," Megasains. 2013; 4: 117 - 123.

[6] M Madlazim. Coulomb Stress Changes Due To Recent Aceh Earthquakes, J. Penelit. Fis. dan Apl. 2015; 5(1): 9-14.

[7] FA Pratikno, G Rachman, BJ Santosa. Coulomb Stress Analysis of Halmahera. 2019; 30(2): 41-44.

[8] D Kusumawati, DP Sahara, AD Nugraha, NT Puspito. Stress drop, earthquake aftershocks and regional stress relation based on synthetic static Coulomb failure stress model, J. Phys. Conf. Ser. 2019; 1204(1): 0-10.

[9] IMKA Astra. COULOMB STATIC STRESS CHANGE DALAM INTERAKSI GEMPABUMI DOUBLETS 5.8 Mw DAN 5.9 Mw 22 JANUARI 2007 DAN GEMPABUMI 7.0 Mw 16 JUNI 2010 DI WILAYAH PAPUA, J. Meteorol. dan Geofis. 2011; 12(1): 103-111.

[10] A Wibowo, P Supendi, AD Nugraha. Coulomb Stress Change of Mw 7.5 Palu-Donggala Earthquake, Sulawesi (28 September 2018), J. Geofis. 2020; 18(1): 19.

[11] B Shan, X Xiong, R Wang, Y Zheng, RBS Yadav. Stress evolution and seismic hazard on the Maqin-Maqu segment of East Kunlun Fault zone from co-, post-and interseismic stress changes, Geophys. J. Int. 2015; 200(1): 244-253.

[12] B Shan, X Xiong, R Wang, Y Zheng, S Yang. Coulomb stress evolution along Xianshuihe-Xiaojiang Fault System since 1713 and its interaction with Wenchuan earthquake, May 12, 2008, Earth Planet. Sci. Lett. 2013; 377-378, 199-210.

[13] Y Wan, ZK Shen. Static Coulomb stress changes on faults caused by the $2008 \mathrm{Mw} 7.9$ Wenchuan, China earthquake, Tectonophysics. 2010; 491: 1-4: 105-118.

[14] B Maleki Asayesh, S Zarei, H Zafarani. Effects of imparted Coulomb stress changes in the seismicity and cluster of the December 2017 Hojedk (SE Iran) triplet, Int. J. Earth Sci. 2020; 109(7): 2307-2323.

[15] S Toda, J Lin, RS Stein. Using the $2011 \mathrm{Mw} 9.0$ off the Pacific coast of Tohoku Earthquake to test the Coulomb stress triggering hypothesis and to calculate faults brought closer to failure, Earth, Planets Sp. 2011; 63(7): 725730 .

[16] J Fisika, et al. Penentuan Prekursor Gempa Bumi Menggunakan Data Magnetotellurik Di Daerah Pelabuhan Ratu, Youngster Phys. J. 2013; 2(3): 115-120.

[17] AS Rahmawati, RP Dewi. View metadata, citation and similar papers at core.ac.uk, PENGARUH Pengguna. PASTA LABU KUNING (Cucurbita Moschata) UNTUK SUBSTITUSI TEPUNG TERIGU DENGAN PENAMBAHAN TEPUNG ANGKAK DALAM PEMBUATAN MIE KERING. 2020; 274-282, 2020.

[18] X Xiong, et al. Coulomb stress transfer and accumulation on the Sagaing Fault, Myanmar, over the past 110 years and its implications for seismic hazard, Geophys. Res. Lett. 2017; 44(10): 4781-4789.

[19] B Shan, Y Zheng, CL Liu, ZJ Xie, J Kong. Coseismic Coulomb failure stress changes caused by the 2017 M7.0 Jiuzhaigou earthquake, and its relationship with the 2008 Wenchuan earthquake," Sci. China Earth Sci. 2017; 60(12): 2181-2189. 
[20] T Ishibe, et al. Correlation between Coulomb stress imparted by the 2011 Tohoku-Oki earthquake and seismicity rate change in Kanto, Japan," Geophys. J. Int. 2015; 201(1): 112-134.

[21] T Ishibe, K Shimazaki, H Tsuruoka, Y Yamanaka, K Satake. Correlation between Coulomb stress changes imparted by large historical strike-slip earthquakes and current seismicity in Japan, Earth, Planets. 2011; 63(3): 301-314.

[22] A Loeqman, N Sulaksana, AH Hamdani, W Sulistri. Pemodelan Aliran Awanpanas (Aliran Piroklastik) Sebagai Data Pendukung Peta Kawasan Rawan Bencana Gunungapi (Studi Kasus Gunungapi Sinabung Sumatra Utara), J. Lingkung. dan Bencana Geol. 2017; 8(1).

[23] H Broichhausen, R Muir, C Dunlop, E Macaulay. Elastic Dislocation Modelling and Coulomb Stress Change Investigations *. 2015; 41679.

[24] Y Wang, F Wang, M Wang, ZK Shen, Y Wan. Coulomb stress change and evolution induced by the 2008 wenchuan earthquake and its delayed triggering of the 2013 Mw 6.6 Lushan Earthquake, Seismol. Res. Lett. 2014; 85(1): 52-59.

[25] JC Rollins, RS Stein. Coulomb stress interactions among $M \geq 5.9$ earthquakes in the Gorda deformation zone and on the Mendocino Fault Zone, Cascadia subduction zone, and northern San Andreas Fault, J. Geophys. Res. Solid Earth. 2010; 115(12).

[26] T Lay, TC Wallace. Modern Global Seismology (International Geophysics Series, Volume 58). $1995 ; 58$.

[27] RZ John Jaeger (Author), NG Cook. Fundamentals of Rock Mechanics 4th Edition, 4th ed. USA: BLACKWELL PUBLISHING. 2007.

[28] CU Christopher, H Scholz. Lamont-Doherty Earth Observatory, The Mechanics of Earthquakes and Faulting. USA: Cambridge University Press. 2018.

[29] GCP King, RS Stein, Jian Lin. Static stress changes and the triggering of earthquakes, Bull. - Seismol. Soc. Am. 1994; 84(3): 935-953.

[30] S Hainzl, S Steacy, D Marsan. Theme V - Models and Techniques for Analyzing Seismicity Seismicity Models Based on Coulomb Stress Calculations," Community Online Resour. Stat. Seism. Anal. 2010; 1-25.

[31] Z Zhou, TM Kusky, CC Tang. Coulomb stress change pattern and aftershock distributions associated with a blind low-angle megathrust fault, Nepalese Himalaya, Tectonophysics. 2019; 767: 228161.

[32] M Utkucu, H Durmuş, H Yalçın, E Budakoğlu, E Işık. Coulomb static stress changes before and after the 23 October 2011 Van, eastern Turkey, earthquake (\&lt;i\&gt;M\&lt;/i\&gt;\&lt;sub\&gt;W\&lt;/sub\&gt;= 7.1): implications for the earthquake hazard mitigation," Nat. Hazards Earth Syst. Sci. 2013; 13(7): 1889-1902.

[33] GHD Sinaga, M Zarlis, M Sitepu, RA Prasetyo, A Simanullang. Coulomb stress analysis of West Halmahera earthquake mw=7.2 to mount Soputan and Gamalama volcanic activities, IOP Conf. Ser. Earth Environ. Sci. 2007; 56(1): 3-10.

[34] S Ardiansyah. Kajian Jejak Coulomb Static Stress Change dan Lokasi Gempa Bumi Signifikan Daerah Bengkulu (Periode Tahun 2000 - 2007)," SIMETRI, J. Ilmu Fis. Indones. 2014; 2(1): 11-14.

[35] M Madlazim, BJ Santosa, W Utama. Three Components Seismogram Analysis of Tasikmalaya, Indonesia on September 2nd 2009 Earthquake to Investigate the Coulomb Stress Change and Seismicity Rate Change, Indones. J. Phys. 2010; 21(3): 71-76.

[36] S Eggert, TR Walter. Volcanic activity before and after large tectonic earthquakes: Observations and statistical significance," Tectonophysics. 2009; 471(1-2): 14-26.

[37] TR Walter, R Wang, M Zimmer, H Grosser, B Lühr, A Ratdomopurbo. Volcanic activity influenced by tectonic earthquakes: Static and dynamic stress triggering at Mt. Merapi, Geophys. Res. Lett. 2007; 34(5).

[38] TR Walter, F Amelung, Volcanic eruptions following $M \geq 9$ megathrust earthquakes: Implications of the SumatraAndaman volcanoes," Geology. 2007; 35(6): 539-542. 